\title{
Article
}

\section{Encounters at the end of the world: Max Weber, Carl Schmitt and the Tyranny of Values}

\author{
Cerella, Antonio
}

Available at http://clok.uclan.ac.uk/14248/

Cerella, Antonio (2016) Encounters at the end of the world: Max Weber, Carl Schmitt and the Tyranny of Values. Journal of Cultural Research . pp. 1-20. ISSN 1479-7585

It is advisable to refer to the publisher's version if you intend to cite from the work. http://dx.doi.org/10.1080/14797585.2016.1141833

For more information about UCLan's research in this area go to http://www.uclan.ac.uk/researchgroups/ and search for <name of research Group>.

For information about Research generally at UCLan please go to http://www.uclan.ac.uk/research/

All outputs in CLoK are protected by Intellectual Property Rights law, including Copyright law. Copyright, IPR and Moral Rights for the works on this site are retained by the individual authors and/or other copyright owners. Terms and conditions for use of this material are defined in the policies page.

\section{CLoK}

Central Lancashire online Knowledge www.clok.uclan.ac.uk

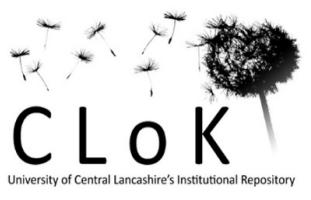




\title{
Encounters at the end of the world: Max Weber, Carl Schmitt and the Tyranny of Values
}

\author{
Antonio Cerella* \\ School of Humanities and Social Sciences, University of Central Lancashire, Preston, UK
}

(Received 10 December 2014; accepted 10 November 2015)

This essay aims at throwing new light on a decades-long controversy over the intellectual relation between Weber and Schmitt. This debate over time has been characterized by polar positions, with the "Weberians" who exclude any continuity between the theorist of Wertfreiheit and the Kronjurist of the Third Reich; and those who not only emphasize similarities, but also a true intellectual filiation between them. Without denying legitimacy to these interpretations, I shall argue that the similarities as well as the differences between Weber and Schmitt are to be found and located in the larger context of the crisis of modernity. Both theorists lived and witnessed the dilemmas caused by the process of rationalization, the neutralization of politics, the technocracy it entailed, and the emergence of a secular polytheism of values. The crisis of modernity - and of political mediation - is the background against which these two thinkers have shaped their conceptual tools but, as I shall explain, the intellectual weapons they used to address this epochal crisis are different. Between the Weberian "ethics of responsibility" and the Schmittian "neutralization of values," there is an abyss crossed by an ideology: the political.

Keywords: Max Weber; Carl Schmitt; theory of values; disenchantment; philosophy of history; political theology
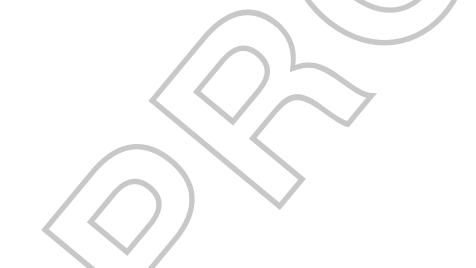

Evil is the starry sky of the Good. ${ }^{1}$

Kafka (1917/1992, p. 57)

Violence has been the sire of all the world's values.

Jeffers $(1941 / 2011$, p. 563)

\section{Introduction}

30 Every new world view arises from a spatio-cultural revolution as well as any thinker is intimately linked to the ethos of his age. Max Weber and Carl Schmitt probably would have shared this vision, convinced as they were of the non-universality of human sciences and of the radical historicity of concepts and ideas. ${ }^{2}$ This conception of intellectual history could also be used to penetrate the epochal background against which the complex relationship between these scholars has gained insights and momentum. Rationalization and disenchantment, secularization and neutralization, theology and theodicy, legality and legitimacy, charisma and katechon; all these conceptual pairs 
represent, in fact, the leitmotivs of Weber's and Schmitt's analyses and lead to a common origin: the crisis of Western rationalism. ${ }^{3}$ Nonetheless, it would be forced to draw the conclusion that Schmitt "was a 'legitimate pupil' of Weber's" or that his work represents a "response of a political thinker to an economist" (Colliot Thélène, 1999, p. 142; Habermas, 1971, p. 66). In the first case, one underestimates the overall context, the crisis of modernity and the cultural and political horizon from which both Schmitt and Weber drawn their themes. The second argument emphasizes personalism, reducing the boundaries of the mundus imaginalis that lies beyond their analyses. I believe, therefore, to be methodologically sound to explore Weber's and Schmitt's intellectual apparatuses not only on the basis of the problems they faced but, above all, via the solutions they elaborated to those challenges, trying to apprehend their "imaginative background.",

Following this approach, this essay aims at throwing new light on a decades-long controversy over the intellectual relation between Weber and Schmitt. ${ }^{4}$ This debate has been characterized by polar positions, with the "Weberians" who exclude any continuity between the theorist of Wertfreiheit and the Kronjurist of the Third Reich (cf. Topitsch, 1971, p. 19); and those who not only emphasize similarities, but also a true intellectual filiation between them (Lukács, 1980, pp. 652-661). Without denying legitimacy to these interpretations, I shall argue that the similarities between Weber and Schmitt are to be found and located in the larger context of the crisis of modernity. Both theorists lived and witnessed the dilemmas caused by the process of rationalization, the neutralization of politics, the technocracy it entailed, and the emergence of a secular polytheism of values. However, while for Weber the age of disenchantment represents the end of any possible ideological unity of the world and, in turn, its reversal in a renewed secular polytheism; for Schmitt, this crisis reveals the origin of politics - i.e. the political that, according to him, becomes the ultimate all-encompassing force.

Colliot-Thélène (1999, pp. 138-141) has suggested three analytical facets of confrontation between these scholars: positivization of law, the theory of values, rationalization and the genesis of modernity. ${ }^{5}$ I think it is particularly relevant to engage with the second line of comparison. Firstly, the link between Weber's theory of values and Schmitt's Tyranny of Values (1960/2011) has not been fully explored. ${ }^{6}$ Secondly, "the theory of values" represents a sort of intellectual testament of these two scholars; indeed, it contains their ultimate conceptual effort through which they tried to rethink the problems of disenchantment and the nihilism it entails. In this sense, the "discourse on values" is also an extreme synthesis of the other two facets of analysis. Finally, Schmitt's (1960/2011, p. 42) essay is the most explicitly "Weberian," the one in which he acknowledges "Weber's intellectual honesty" [Webers intellektuelle Redlichkeit] and the similarities as well as the differences between these authors emerge most forcefully.

Comparing Weber and Schmitt on this conceptual ground, I intend to show how they stand on different "vocational" sides. If, indeed, for Weber (1946, p. 153), the only possibility "in a time without god and prophet" is to take "responsibility before history" "and, therefore, commensurate one own actions on the basis of an adequate individual ethics; Schmitt, on the contrary, believes that behind this Krise lies entropy and violence, the latter being the substantial source of the social life that can change form but cannot be removed from "the normative order of the earth." This is the rift that separates the atheist theorist of The Protestant Ethic from the Catholic author of Politische Theologie. The crisis of modernity - and of political mediation - is the background against which these two thinkers have shaped their conceptual tools but, as I 
shall explain, the intellectual weapons they used to address this epochal crisis are different. Between the Weberian "ethics of responsibility" and the Schmittian "neutralization of values," there is an abyss crossed by an ideology: the political.

\section{Reducing polarity: the Weber-Schmitt controversy}

The controversy over the intellectual relation between Weber and Schmitt has old roots which can be traced back to late April 1964 when - during the Fifteenth Convention of the German Sociological Association held in Heidelberg in honor of Weber's centenary - a young Habermas (1971, p. 66) notoriously stigmatized Schmitt as a "legitimate pupil" of Weber. This view was shared by Lukács (1980, p. 652), one of Weber's old fellow scholars and frequent visitor of the Heidelberg "circle" in the pre-World War I. ${ }^{8}$ Both Lukács and Habermas were convinced that the charismatic element of Weber's Caesar-like leader-democracy passed to the Schmittian notion of decisionism. In truth, the origin of this controversy can be further backdated to a particular reading of Weber as theorist of sheer power politics and herald of Nazism (Schapiro, 1945). ${ }^{9}$ It has been pointed out, however, that this line of thought is characterized by an underlying reductionism, by what Strauss (1953, p. 42) has ironically defined as reductio ad Hitlerum; i.e. the polemical interpretation according to which Weber's thought would have inescapably led to Nazi-fascism. It has been relatively easy, then, for a Weberian like 20 Guenther Roth to label these criticisms "ideological" because, "for ideological reasons," they "cannot recognize any dividing line between political sociology and political ideology” (Bendix \& Roth, 1971, p. 55).

The historical and ideological consequentiality that would have led Weber's Führerdemokratie - via Schmitt - to Hitler's Drittes Reich has been reformulated, historicized,

25 and carried forward by Mommsen (1984) in his pioneering work Max Weber and German Politics. According to him, "Schmitt merely drew radical conclusions from the premises that were already outlined in Weber's theory of legitimacy" (p. 449). Moreover, for Mommsen, Schmitt's critique of partisan pluralism and his theory of plebiscitary authority are nothing but a conceptual "extension of Weber's own program," even 30 though - as he acknowledges - Schmitt developed his radical conclusions on political leadership "by the thorough repression of all constitutional safeguards that Weber had included" (pp. 382-3). Although very well documented, this seminal work rests on a problematic methodology. From the outset, Mommsen (1984, p. xvii) declares that, while previous works had usually tried to interpret Weber's ideas and political thought

35 by reference to his theoretical writings, he undertakes the opposite approach of tracing "Weber's development as a politician by means of a detailed assessment of his position on the day-to-day political issues."10 This intellectual path, in my view, overlooks the dialectical relationship between theory and practice that is essential to understand Weber's work. ${ }^{11}$ In fact, he is among the few scholars for whom the relevance of the40 ory lies in historical contingency as much as critical reflection on political praxis rests on a momentous historical-theoretical crisis. As he put it, "it is always by the demonstration and solution of problems of substance that new sciences have been established and their methods further developed" (Weber, 2012, p. 140). The amalgam of theory and practice is especially, and "dangerously," vivid in Schmitt's work (2005, p. 34).

45 According to the legal theorist, "the distinction between theory and practice is one of the consequences of the modern political thought which no longer possesses a concept of nature." 12 
In this regard, McCormick (1998, p. 174) has highlighted how Schmitt's work can be read precisely as an attempt to overcome the Weberian categories in order to transcend the divides created during modernity between subject and object, nature and culture, theory and practice; a radical yet failed attempt that did not succeed in overcoming in toto "Weber's irrational tendencies." 13 For McCormick, it was Weber's neo-Kantian ideal of a "liberal" social science the target of Schmitt's criticisms and theorizations. He cites a passage from Die Tyrannei der Werte to support his thesis (cf. McCormick, 1998, pp. 175-6). Nonetheless, the passage is misleading and decontextualized because if read in its entirety, it would suggest not a critique but, on the contrary, an endorsement of Weber's position. For, in discussing Raymond Aron's interpretation of Weber's vocational conferences, Schmitt (1960/2011, p. 42, my emphasis) stresses how "it would be obviously wrong to reduce him [i.e. Weber] to some powerful passages, neglecting his broader sociological insights. Moreover, no one thinks to tie him down [festzulegen] to his neo-Kantian epistemology." As we shall see in the next sections, it is precisely from Weber's "post-Kantian awareness" that Schmitt attacks the philosophical pretension to build an objective system of values.

This brief overview of the debate indicates quite clearly a fundamental difficulty in reconstructing the relationship between these two thinkers, which is partly due to the polarization of the academic positions but, above all, to the ambiguity through which Schmitt confronted himself with the sociologist of Erfurt (cf. Ulmen, 1985, p. 5). The latter was equivocally defined by Schmitt (1950/2001, p. 62) as "the great German sociologist" or as an "intolerable" scholar/with whom he felt disgusted for the "seething irrationality" of his thought that "with spasmodic convulsions tries to cover itself with rational fig leaves" (Schmitt, 1991, p. 113). As a matter of fact, Schmitt's judgment on Weber's work - always fragmented and never systematic ${ }^{14}$ - changes and evolves over time. It has undergone substantial modifications due to personal and historical experiences over the course of an almost centenarian life. It has been suggested, however, that this ambiguity could be the expression of the so-called Schmitt's "occasionalism" and, accordingly, of the impossibility to establish with certainty his "ultimate standpoint." For, "Schmitt's profane decisionism" - Löwith (1935/1995, p. 144) has argued:

is necessarily occasional because he lacks not only the theological and metaphysical presuppositions of earlier centuries but the humanitarian-moral ones as well. [...] What Schmitt defends is a politics of sovereign decision, but one in which content is merely a product of an accidental occasio of the political situation which happens to prevail at the moment.

Without pretending to formulate a definitive interpretation of the intellectual relationship between these two scholars - or resorting to the "spark" of the occasio to explain the oscillating ambiguity that characterizes it - the theory of values is used here as a "Trojan horse" to decipher the continuity/discontinuity in the Weber-Schmitt relation. I believe that behind their reasoning for values lay some crucial categories that might provide an understanding - if not unitary, at least substantive - of their thought. The fruitfulness of this analytical approach, I argue, lies in the possibility of tracking down a profound philosophical core upon which Weber and Schmitt rooted two different conceptions of history and politics. This attempt requires a genealogical reconstruction of their intellectual journey that has its apex in the theory of values. Their "narrative of values," in fact, does not merely rest on a scientific conception or historical experience, but also on a different "image of history," of its progress and meaning. In this sense, it 
mirrors an ontological distinction between these two German scholars. In other words, the discourse on values - in the thought of Weber and Schmitt - begins not at the inception but at the end of a crisis. For them, the question of the foundation of values is not an ontological problem per se, but an historical one which becomes ontological once the process of rationalization-secularization has exceeded a certain critical threshold: modernity.

\section{A short genealogy of 'value': origins, evolution, and fragmentation}

The value has its own logic, i.e. "those who speak of value want to valorize and to impose." For, "no one can evaluate without devaluing, revaluating, and exploiting. Whoever sets values has thus already positioned himself against non-values [Unwerte]" (Schmitt, 1960/2011, pp. 44-46). This is, in a nutshell, Schmitt's position on the problem of values. To understand its historico-political effectiveness, it is necessary to situate this view within the larger debate on the problématique of values that emerged in the nineteenth century, matured at the fin de siècle and exploded into full force in the 15 twentieth century. ${ }^{15}$ Value is, in fact, a keyword, a symbol of the Western historico-political-philosophical development; "one of the best physiognomic features to design the profile of the current age" (Ortega y Gasset, 1923/2004, p. 11). In its conceptual history, it enshrines and condenses the crisis and parable of modernity. In particular, two epochal trajectories intersect and overlap within this "conceptual container": the process 20 of secularization of ethics and the economization of the social world. These are two parallel and contiguous developments that, over time, tend to imbricate. On the one hand, therefore, in the words of Weber $(1949$, p. 107), who emphasizes its economic and political filiation, the term "value" is the "unfortunate child of misery of our science"; i.e. the mature fruit of that "spirit of capitalism" that has now become "victo25 rious." 16 On the other hand, for Schmitt, this term embraces a "crisis of disenchantment"; i.e. values try to fill the chasm opened by nihilism, the horror vacui produced by the decline of ethics: "value and what is valuable are turned into a positivistic surrogate [Ersatz] for the metaphysical" (Schmitt, 1960/2011, p. 37). ${ }^{17}$ For the two scholars, in sum, values emerge when the economic rationalization and disenchantment have 30 wrapped the social world in a fog like ghosts of a by-now-extinct ethos.

As a matter of fact, in an ethical sense, the ancients did not know the concept of value, but rather that of Good ( $\dot{\alpha} \gamma \alpha \theta$ óv). Plato (1902, p. 60), for instance, has Socrates say in The Republic that the "thing which gives the things which are known their truth

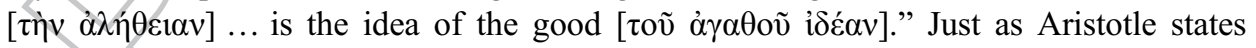
(1894, p. 138), although from a very different perspective, at the beginning of the First

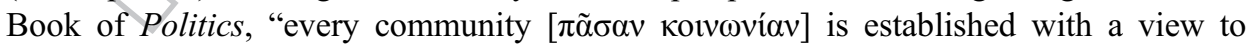

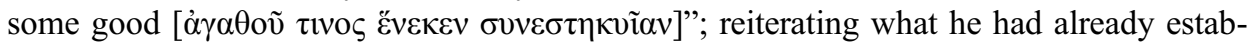
lished in the Nicomachean Ethics (1900, p. 9), i.e. that "the knowledge of the good" is

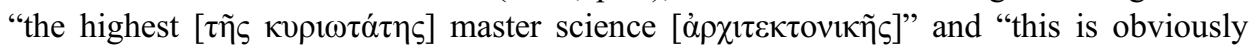

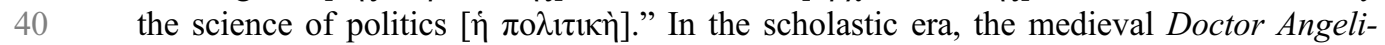
cus Aquinatis Aquinatis, (1862, p. 236), following the classical notion, could still write in his Summa contra Gentiles: summum igitur bonum, quod est Deus, est causa bonitatis in omnibus bonis (the highest good which is God is the cause of the goodness in all good things). What we have, therefore, is an ethical notion of good thought of as either transcendent or objective. Whether conceived as an archetype, principle of reason or Divinity, the Good - and not value - is the North Star toward which humanity should point. It can be thought of as transcendence that determines and qualifies immanence, 
or "the Good above all that is good" according to the well-known definition by Plotinus (1956, p. 620). However, this meaning gets progressively lost with the decline of the medieval age and the advent of modernity. The first partial break occurs with Hobbes $(1651 / 2005$, p. 144) who, in the Leviathan section devoted to the "rights of sovereigns," discusses those "values men are naturally apt to set upon themselves." 18 Yet, Hobbes here maintains the Latin root of the word. Value is still understood as virtus and honor. ${ }^{19}$ AQ13 It is therefore only thanks to the classical economists, in particular Smith (1776) and AQ14 Ricardo (1817), that the term value becomes popular and spreads beyond the boundaries of the economic field. And the greater the diffusion, the more subjectified the concept, absorbing in its semantic field other forms of knowledge. Thus, value is turned into a polysemic term that embraces all modes of being: there are cultural, aesthetic, political, economic, artistic values, etc. (cf. Volpi, 2008).

Kant is perhaps the last thinker who tried to distinguish between ethics, dignity, and value while, at the same time, recomposing the fracture that occurred between the subject (dignitas) and the object (value). In Die Metaphysik des Sitten (1797/1996, p. 186), discussing the doctrine of virtue, he differentiates "a human being (homo phaenomenon)" who in the mere system of nature is simply "a being of slight importance and shares with the rest of the animals ... an ordinary value (pretium vulgare)" from a human being "subject of morally practical reason," namely regarded "as person (homo noumenon)." The latter cannot "be valuated merely as means to the ends of other or even to his own ends, but as an end in himself" because "he possess a dignity (an absolute inner worth)." For Kant (1797/1996, p. 187), it is the moral duty that elevates human subjectivity toward universality, compelling the human being to revere his own person, to feel "his inner worth (valor), in terms of which he is above any price" (pretium), and "instills in him respect for himself (reverentia)." As Schmitt (1960/2011, p. 12-14) remarks at the beginning of his essay, this fundamental distinction between the value of things and the dignity of the person got completely lost because "a hundred years of rapid industrialization has essentially transformed value in an economic category," so that "a metamorphosis in values, a general valorization [allgemeine Ver-Wertung], is now taking place in all spheres of our social existence."

Yet, there is more. As previously mentioned, this process of economicization of social life is intimately linked to the collapse of the Christian ethos and the secularization of its ethics. While, under the pressure of the capitalist spirit, we witness the economization of life, in which everything becomes commensurable; on the other hand, and specularly, we observe the fragmentation of ethics in a multiplicity of values "ethically devalued." This crucial moment in Western history has been described with extraordinary force as the advent of the "uncanniest of all guests": nihilism (Nietzsche, 1906/ 1968 , p. 7). It is Nietzsche, in fact, that through his attempt at an Umwertung aller Werte brings the category of value at the center of the political and philosophical debate. As Heidegger (1943/2002, p. 169) has acutely argued, "in the nineteenth century, talk of values became frequent, and it became customary to think in values. However, it was only as a consequence of the broadcasting of Nietzsche's writings that talk of values has become popular."

"What does nihilism mean?" - Nietzsche (1906/1968, p. 9) asks at the beginning of The Will to Power. "That the highest values devaluate themselves. The aim is lacking; 'why?' finds no answer." It is in this chasm opened by nihilism, in this loss of meaning of ancient morality, that values take the center of the speculative stage. Nihilism erodes the place of Christianity because, as Nietzsche $(1906 / 1968$, p. 7) points out, it is in the end of Christianity that it is rooted. At the same time, however, the abyss left open by 
the "death of God" is not refilled. Nihilism reveals this fundamental event without replacing it, but rather leaves all questions suspended and unanswered. What happens to ethics after the "death of God"? What do values represent for the human being once they have been stripped of the alleged objectivity of Christianity? What does it entail to live and think in terms of values in the political sphere?

Nietzsche's philosophy thus brings to the center of the philosophical debate the problématique of values declined through the conceptual fracture opened between subject and object, in the "antithesis between an interior which fails to correspond to any 10 exterior and an exterior which fails to correspond to any interior" (Nietzsche, 1874/ 2007 , p. 78). On the one hand, this opens the way to the question as to how to re-establish an ethical personalism through which "to bear the entire and ultimate responsibility for your actions yourself and to relieve God, world, ancestors, chance and society of the AQ15 burden" (Nietzsche, 2002, p. 21). On the other, it raises the dilemma of how to reconsti15 tute an objectivity, a solid foundation, when even the concept of "necessity" has become nothing more than a "conventional fiction," where in the "itself" there is nothing like necessity; in a world, in short, in which "there is no rule of 'law'." It is around these issues that a genuine Wertphilosophie arises. Initially, from within the neo-Kantian School of Baden, thanks to the work of Wilhelm Windelband and Heinrich Rickert. The latter in his book The Limits of Concept Formation (1802/1986, pp. 215-6), trying to re-establish a philosophy of history on axiological basis, when "neither empirical actuality [Wirklichkeit] nor a metaphysical reality [Realität] is qualified to endow ... science and history with objectivity," had determined that "this objectivity can be grounded only on the validity of theoretical values." Accordingly, this way of thinking led to the belief 25 that "historical science must be allowed to assume that the unique development of reality stands in a necessary relationship to some unconditionally and generally valid values" (p. 223). The objectivity of history was therefore recovered through recourse to the category of general values of universal validity. As well known, Weber was initially influenced by Rickert - especially by the notion of Wertbeziehung (value relation) - in developing his epistemological works. ${ }^{20}$ Yet, it is precisely by breaking away from the neo-Kantian positions of the Baden School that Weber would succeed in developing an original theory of values. ${ }^{21}$ As we shall see, it is from within the crisis of the philosophy of values that Schmitt and Weber would try to redesign the boundaries and meaning of this category.

\section{The end of a world: the value of history within the history of value}

On 2 April 1913, Weber (2012, p. 406) writes to his friend Robert Wilbrandt: "I hold the view that what dominates the sphere of values is the irresolvable conflict, and consequently the necessity of constant compromises; no one, except a religion based on 'revelation', can claim to decide in a binding form how those compromises should be

40 made." This view, already violently questioned at the time of Weber - and who accompanied him for most of his life - appears in a similar form in several of his writings AQ18 (cf. Weber, 1904/2012, p. 103; 1917/2012, p. 314; 1922/2012, p. 348). In the AngloSaxon world, it has been described as the antithesis between facts and values, or facts and decision (Löwith, 1964, p. 509). Factor and Turner (1979, p. 304, my emphasis), for example, by analyzing what they call the Weberian doctrine of irreconcilability between facts and values, argue that Weber would have postulated that "value positions are ultimately non-rational" and, for this reason, would not be susceptible to compromise. Moreover, Weber would have developed this position without having 
actually discussed (and confute) all previous philosophical doctrines (Mill, Durkheim, Hobhouse, etc.) according to which the value positions may indeed be rationally justified. Accordingly, Weber would have exposed himself to the risk of irrationality by excluding a priori the possibility of "rational dialogue between valuative positions and other positions" (p. 304).

Here we encounter, in my view, an initial misunderstanding of Weber's position. When Weber (1919/1946, p. 147) states "the impossibility of 'scientifically' pleading for practical and interested stands," he is not suggesting that the spheres of value, given their incommensurability, are not subject to rational discussion. For, irrationality does not concern the positions, their potential discursivity or intelligibility, but their foundation. What is worthy of being known, lived, and fought for, cannot be ascertained objectively by means of science but "can only be interpreted with reference to its ultimate meaning, which we must reject or accept according to our ultimate position towards life" (Weber 1919/1946, p. 143). In other words, for Weber, rationality cannot establish itself as sovereign, cannot objectively take root in history, and cannot scientifically prove its necessity. There is no question of criticizing the limitations of the Weberian conception of rationality, but it is rather important to understand the logical and historical limits of reason. In discussing this issue, for instance, Herbert A. Simon has emphasized:

In the domain of reasoning, the difficulty in finding a fulcrum resides in the truism "no conclusions without premises." Reasoning processes take symbolic inputs and deliver symbolic outputs. The initial inputs are axioms, themselves not derived by logic but simply induced from empirical observations, or even more simply posited. [...] Axioms and inference rules together constitute the fulcrum on which the lever of reasoning rests; but the particular structure of that fulcrum cannot be justified by the methods of reasoning. For an attempt at such a justification would involve us in an infinite regress of logics, each as arbitrary in its foundations as the preceding one. [...] The corollary to "no conclusions without premises" is "no ought's from is's alone." Thus, whereas reason may provide powerful help in finding means to reach our ends, it has little to say about the ends themselves.

(Simon, 1983, pp. 5-7) $)^{22}$

The problem of values is, therefore, that of their foundation. Here what is at stake is not merely whether they can be rationally discussed or universally justified. The question is not, to quote Nietzsche (1886/2002, p. 13), "how are synthetic judgment a priori possible?" but rather "why is the belief in such a judgment necessary?" As we shall see, for Weber and Schmitt rationality, once entered the world of historical becoming, is not at all necessary and cannot avoid the irreconcilability between the various subjective points of view that - as all equally unfounded - are considered "dangerously" objective.

Strauss (1953, p. 42) has described this position as nihilistic because, embracing the Weberian thesis, "every preference, however evil, base, or insane, has to be judged before the tribunal of reason to be as legitimate as any other preference." He finds intolerable (1953, p. 48, my emphasis) that one considers "equally legitimate to will or not to will truth, or to reject truth in favor of the beautiful and the sacred. Why, then, should one not prefer pleasing delusions or edifying myths to the truth?" However, as is clear from this passage, Strauss' critique is based on notions of truth (understood as logical adequacy) and rationality that are geographically and historically limited, and yet for him they become the fulcrum of a universalist vision of ethics and nature. ${ }^{23}$ Good and evil, truth and justice are concepts that Strauss inherits from a "noble" tradition entered into crisis after all former illusions, "the 'way to true being,' the 'way to 
true art,' the 'way to true nature,' the 'way to true God,' the 'way to true happiness,' have been dispelled" (Weber, 1919/1946, p. 143). What is the "true Truth" that reason must inspire, search for, and preserve in an age in which the intellectual and spiritual center is lacking? "[W]hat meaning does our being have, if it were not that will to truth has become conscious of itself as a problem in us?" (Nietzsche, 1887/2013, p. 273). As Löwith has correctly argued:

[...] both opponents and advocates of the separation between knowledge and evaluation misjudge Weber's central motif of this distinction; i.e. the recognition that today we live in a world that is objectified by scientific technology and that, on the other hand, the objective rationality of science has freed us from general and binding norms of moral and religious type. Therefore, our old values cannot rely on traditions or be scientifically justified, because good and evil are now matter of personal decision. (Löwith, 1964, p. 509-510)

15 Strauss' critique then misses its target because the problem raised by Weber is not that of the negation or rational re-establishment of a universal pivot (Strauss' "natural law") through which to face the advancement of nihilism and extreme relativism. The thesis of the heterogeneity of values illuminates a substantive - and not formal - historicoontological problem. The fragmentation brought about by the disenchantment by means 20 of technology is both a subjective liberation and a destruction of the collective center. When the Christian ethos, perceived as objective, collapses under the blows of science and technology, a fulcrum capable of recomposing the fragmentation can no longer be recreated because the techno-scientific dynamic transforms the infinite progressivism and groundlessness into its own ontology. For Weber, therefore, disenchantment means 25 the end of "the faith in some kind of 'objective' meaning [...] Since all objectives have lost their objective meaning as a result of the rationalisation carried through by human beings, they are now available to human subjectivity in a new way: for the determination of their meaning" (Löwith, 1932/1993, p. 76). The ratio, in sum, is no ethos. It does not coagulate actions and perceptions in a form of life that is concretely and $o b$ 30 jectively universal; it does not transform a syllogism into conduct of life. Albeit the supreme and ultimate value judgments give meaning and direction to our lives, so that they are experienced as something objectively significant, they have their ultimate foundation in the sphere of individuality. Consequently, on the ground of history, there are no universally just and necessary values, but only values believed to be such. "It is the 35 fate of our culture, however, that we are again becoming more clearly aware of this situation, after a millennium during which our (allegedly or supposedly) exclusive orientation toward the sublime fervor of the Christian ethic eyes had blinded us to this situation"(Weber, 1919/2012, p. 348).

For these reasons, Weber rejects the metaphysical anchorage (metaphysische Veränkerung) proposed by Windelband (and then again, in a different form, by Rickert). For the neo-Kantian philosopher if "truth is not our discovery or our illusion, but a value that is rooted in the ultimate depths of reality," this means that "the life of values demands a metaphysical anchorage, and, if we give the name God to this super-empirical vital connection of personalities, we may say that his reality is given in the reality 45 of conscience itself" (Windelband, 1914/1921, p. 326). But Weber cuts the Gordian knot that binds the metaphysical universal to the historical particular because once "God is dead, there is no grounding by which one perspective could have legitimacy over other perspectives" (Löwith, 1993, p. 18). There is no a priori or axiology that holds back reality once truth from certainty and axiom has become problem and abyss 50 of meaning: 
The fate of an epoch which has eaten of the tree of knowledge is that it must know that we cannot learn the meaning of the world from the results of its analysis, be it ever so perfect; it must rather be in a position to create this meaning itself. (Weber, 1904/1949, p. 57).

Weber's departure from the neo-Kantian school, therefore, takes place precisely on the grounds of a historical crisis (disenchantment) that reveals an ontological problématique (the groundlessness of the center): the de facto impossibility of an objective evaluation via the sciences and, at the same time, the concrete and substantive impossibility of finding a universal pivot upon which to establish an objective ethics to guide politics and public morality. As predicted by Rickert (1902/1986, p. 220), "such a doubt, however, if carried out consistently for all values, would destroy the concept of truth itself." How to recompose a unity, then, from the fragmentation of subjective yalues? How is it possible to create an order in the age of the new secular polytheism? And what is the relationship between the political realm and that of values? These are the questions that Schmitt, following the Weberian discourse, will try to develop.

\section{The value of politics and the politics of values}

The "principle of groundlessness" just explored raises two interrelated issues, which rest on the same ontology (i.e. the crisis of the metaphysical center): (1) Epistemologico-methodological: science cannot decide, with its own means, which values we should embrace; (2) Ethico-political: since values are perceived subjectively as something universal and objective, they tend to promote ideological absolutism and moral exclusivism. The latter issue is grounded on a fundamental problem: once the sky has lost its "transcendental cover," it tends to be "repainted," as it were, with the subjective colors of ideology; in the age of immanence, the ancient gods, stripped of their enchantment and in impersonal form, dominate again people's lives. In Weber's words, "so long as life remains immanent and is interpreted in its own terms, it knows only of an unceasing struggle of these gods with one another. Or speaking directly, the ultimately possible attitudes toward life are irreconcilable, and hence their struggle can never be brought to a final conclusion" (Weber, 1946, p. 152). Not even the "temperate objectivity" of apriorism can resolve this tension inherent in acting in the era of disenchantment. In a yery dense fragment that is worth quoting in extenso, Weber (2012, pp. 421-2) expressed in this way his dissent from the Kantian perspective:

Formal ethics has to face the fact that its propositions do not enable it to deduce substantive conclusions - even within the ethical domain itself, let alone concerning conflicts between value spheres. An attempt to perform such a deduction would be just as sterile as if one wanted to deduce, say, substantive chemical facts from logical propositions. The Kantian imperatives, too, are valid analysis of certain elementary facts concerning the way in which ethical judgments are made. Irrespective of the function that they may consequently have in connection with substantive decisions in the field of ethics, they in any case do not support any kind of decision concerning the ethically irrational conflict of the value sphere. ${ }^{24}$

For Weber, in short, there would be a sort of hiatus irrationalis between formal ethics - which rests on an abstract logic - and historical values - which are linked to concrete substances and subjectivities. Abstract logic cannot stem the desire that inspires concrete historical action. On the other hand, when action enters history, it has to deal with "the meaningless infinity of the world process." It has to accept, therefore, that this challenge and its destiny are not completely rationalizable. In other words, logic 
cannot restrain "das Konkretissimum des Erlebens" (the concreteness of experience; cf. AQ23 Schmitt, 2011, p. 22; Weber, 1922, p. 428).

Carl Schmitt essentially agrees with this position. For him, the logic of value is in fact characterized by an "immanent aggressiveness" because values - although high, sacred, and just - push to be constantly actualized, and can only be realized by someone against someone else: "Whether something has value and how much, whether something is worthy and to what extent can be determined only from an assumed point of view or particular vantage-point. The philosophy of values is a point-philosophy [Punkt-Philosophie]; the ethics of value a point-ethics [Punkt-Ethik]" (Schmitt, 2011, p. 41). This "prospective pointillism" is intrinsically dangerous because "values as such are brought by actual [konktreten] people to bear upon other actual people." Accordingly, "the genuinely subjective freedom of value-setting leads [...] to an endless struggle of all against all, to an endless bellum omnium contra omnes" (p. 45, 39).

15 As known, it is precisely to square the circle of practical philosophy and to mediate between the concreteness of action and the need for a non-formal ethics that Max Scheler (1916/1973, p. 6) had attempted to recovery the category of value and to overcome Kant's "empty apriorism," as it "bars us from any true insight into the place of moral values in man's life." For Scheler (p. xxix), overcoming Kant's formalism means to build a 20 system of values based on "the living center of individual person" without neither depriving her of the historical-relativist habitus nor renouncing to the universality of the "idea of an absolute ethics itself." Howeyer, Schmitt attacks Scheler's pretension to build a non-formal [material] and universal axiology. For, in the realm of the political, values positions are subject to a fatal reversibility and get constantly overturned, so that "their 25 meaning and function [...] change with the changing planes" (p. 42). Is not enough, therefore, to build a scale of values, as Scheler does, to hold on and stem the crisis of nihilism and the dangerous freedom of the subject to decide:

To claim an objective character for values which we set up means only to create a new occasion for rekindling the aggressiveness in the struggle of valuations, to introduce a new instrument of self-righteousness, without for that matter increasing in the least the objective evidence for those people who think differently. The subjective theory of values has not yet been rendered obsolete, nor have the objective values prevailed: the subject has not been obliterated, nor have the value carriers, whose interests are served by the standpoints, viewpoints, and points of attack of values, been reduced to silence. (Schmitt, 2011, p. 46)

35 The thetically grounded structure [thetisch-setzerischen Struktur] of values emerges in all its strength when one considers the concept of Angriffspunkt. According to Schmitt, when Weber uses this expression, he literally means it as "point of attack." 25 To think along the logic of values means - knowingly or unknowingly - thinking attack strategies. In the world of values, therefore, there would be no room for a weak conceptual 40 relativism, but only for the potential aggressiveness inherent in the purely subjective freedom to reason in terms of values (the potential to attack, in fact).

This latent conflictuality becomes more evident in the political realm. According to Weber $(1946$, p. 121, 124), for instance, "[f]rom no ethics in the world can it be concluded when and to what extent the ethically good purpose 'justifies' the ethically dan45 gerous means"; and this is because "the specific means of legitimate violence as such in the hand of human associations [...] determines the peculiarity of all ethical problems of politics." The sphere of politics is, therefore, different from that of morality and ethics because in it lurks the constant possibility of violence, the tragic tension between different world views. This position is typical of classical realism and can be traced back up to Machiavelli. According to Berlin (2001, p. 74), for example, 
Machiavelli's cardinal achievement would be "the recognition that ends equally ultimate, equally sacred, may contradict each other, that entire systems of value may come into collision without possibility of rational arbitration." Politics (the sphere of conflict) and ethics (the sphere of values) would be two worlds toto caelo different, which is necessary to keep distinct and distant. This is the reason why, according to Weber, it is essential to structure the conflict within the parliamentary system. If "all politics is essentially struggle," it becomes crucial then to select adequate political leaders through a battle that takes place within the political boundaries of the parliament (Weber, 1918/2007, p. 219). Parliament provides the public arena in which political struggle is transformed into discussion and selection.

It is at this level, then, that we encounter a first difference between Weber and Schmitt. When Weber speaks of struggle and conflict, Schmitt translates with violence and annihilation. If for Weber politics is struggle (Kampf), for Schmitt (1932/2007, p. 33) das Politische implies "the real possibility of physical killing." For the sociologist of Erfurt, in short, struggle does not automatically translate into violence and bellum omnium contra omnes (as for Schmitt) precisely because the fragmentation of values can (and should) be caged within institutional and democratic arenas. If it is true that between values there is a an "irreconcilable death-struggle [...] like that between 'God' and the 'Devil,", it is equally true that "[t]here are, of course, as everyone realizes in the course of his life, compromises, both in fact and in appearance, and at every point. In almost every important attitude of real human beings, the value-spheres cross and interpenetrate" (Weber, 1949, p. 17-18). This means that for Weber the clash is not inevitable, and fragmentation - the pluralism of values and, accordingly, of parties can be reassembled in the political arena. Moreover, Weber's emphasis is always on the individual, both in the form of the charismatic and religious leader. In the vast Religionssoziologie, the individual plays a central role in the exploration of historical tendencies. It goes without saying that, given his anti-liberalism, there is no trace of this methodological individualism in the work of Schmitt. This difference is not only the sign of a different methodological choice. Quite the contrary, Schmitt's anti-liberalism, although ideological, is rooted on a precise ontology: in the void of meaning of the era of disenchantment, the individual cannot self-represent himself, is not capable of creating any unity. This crucial position can already be found in his early works. In Der Wert des Staates, Schmitt, for example, states (1914, p. 4): "If anything can be said of individuality, it is because the object of the predicated individuality has been already defined as attribution point for an evaluation under norms." This means that the individual does not exist outside the law that constitutes him; and since the idea of law is not self-grounded but needs to be actualized, the state becomes the form to which Schmitt (1914, p. 2, 93, my emphasis) entrusts the establishment of justice: "the sense of the state consists exclusively in the task of actualizing Law into the world [Recht in der Welt]" and, in this sense, "it is not the state a construction that people have made but, on the contrary, the state makes every man into a construction."

If it is true therefore that Weber follows the classical realist doctrine, with its rigid dualism between public and private ethics, and the consequent primacy of political (salus rei publicae suprema lex), that of Schmitt is a dualism of different origin and nature. Weber, in fact, posits a political unity necessarily given and unproblematic as the foundation of a public sphere. The parliament can play a selective and discursive function just because it is "sealed," as it were, within the state. But for Schmitt (1923/ AQ24 2000, p. 6), this mechanism is now in crisis "because the development of modern mass democracy has made argumentative public discussion an empty formality." The political 
chambers cannot contain the popular energy that spurts out of the institutions in the era of the "revolt of the masses." The ethic of the state then becomes an ethic of emergency, a "hunt of the political": "Political unity is the highest unity - not because it is an omnipotent dictator, or because it levels out all other unities, but because it decides, and has the potential to prevent all other opposing groups from dissociating into a state of extreme enmity - that is, into civil war" (Schmitt, 1930/1999, p. 203). Behind the necessity and the superiority of the state, there is always, for Schmitt, the deconstructive power of the political. The salvation of the state is not "the greater good" because, like for Weber, the Nation is more important than the individual, the collectivity counts more than the Ego, and the private cannot exist without the public, but rather because 15 individuals are seen as carriers of the deconstructive potential of the political, of its never-ending intensity.

Although this view certainly reveals what Löwith (1935/1998, p. 166) has defined "the catastrophic manner of thinking characteristic of the generation of Germans after the First World War," it also conceals a deeper core that makes the differences between

20 Schmitt's and Weber's thought more evident. While, in fact, for the latter, as we have seen, the era of disenchantment is characterized by a fragmentation of values - and the deconstruction of the religious cosmos - for Schmitt, secularization assumes, paradoxically, a theological form. The theological, in other words, leaves an irreducible remain in modernity: the compulsion toward order (Galli, 1996). For Schmitt, the problem of unity is the "white shadow" that the theological casts on modernity. And since this unity is no longer representable by means of transcendence, it has to reconstitute itself in a void of meaning. The state - unfounded but constantly forced to refound itself must represent itself vis-à-vis nothingness, in the face of death. The modern political form therefore becomes nihilistic representation, opening in front of death; murder sus30 pended in time, eternally possible and postponed. In this sense, it should also be read the so-called Schmitt's decisionism. The sovereign - who is not a specific person even though is an actual agent - is the one who is capable of deciding the enemy in order to constitute his own political unity. Such a unity - sovereignly created but always at risk of disintegration - to be preserved has to remain open as totality (friend) in front of death and represent itself vis-à-vis its negation (enemy). We touch here the extreme limit of the biopolitical conception: life (conceived as bio-totality) to preserve itself must constantly be exposed to death. The state "cannot permit its members to die for their beliefs or to commit suicide, when the political unity of those members demands the sacrifice of life" (Löwith, 1935/1998, p. 153). The living being is thus sucked into 40 the Leviathan's maw.

It is at this point that the crucial difference between Weber and Schmitt emerges in full force. Weber too, as is well known, advocates a form of decisionism. For him too decision "opens" history. Yet, for Weber, the ontological significance of the decision lies in the search for meanings in an era devoid of Meaning. The human being - as a cultural being - is a seeker and creator of meanings, and decision represents the ethical choice of the individual in the age of disenchantment:

life as a whole, if it is to be lived in full awareness and is not just to unfold like a natural event - involves a series of fundamental decisions through which the soul, as Plato describes it, chooses its own fate, - the meaning, that is, of its activity and being. (Weber 1917/2012, p. 315)

It is, therefore, upon the ontology of decision in the midst of the "vacuum of values" that Weber and Schmitt meet for a last time, revealing their differences. Ultimately, the 
Schmittian decision-for-the-form and the Weberian decision-for-the-meaning rest on two "ethical worlds" that are light years away from each other.

\section{Conclusion: ethics in the immediacy of the world}

The discourses of Weber and Schmitt on values represent two different - if contiguous - attempts to respond to the crisis of meaning in the age of immanence. As I tried to show, while Schmitt promotes a leviathanic vision of ethics and politics, Weber attempts to safeguard the rationality of the individual because he believes that the ratio becomes all the more important when it lacks a foundation. Thus, in modernity, freedom becomes an absolute negative: freedom from any foundation. Knowing how to accept - and measure with responsibility - the risks and potentialities that this freedom involves means being able "to countenance the stern seriousness of our fateful times."

Schmitt, on the other hand, cannot accept this position because he sees in the "mystery of the political," and the violence that it entails, the last remaining force. This violent fate becomes all the more acute in the age of "unstructured immanence" and of the crisis of the state in which values, like loose cannon, collide with one another. If, in fact, "the idea needs mediation, value demands much more of that mediation." If the center and its boundaries are lacking, then for Schmitt the purpose of justice becomes "to prevent the terror of the immediate and automatic enactment of values" (Schmitt, $1960 / 2011$, p. 54). However, in this writer's opinion, this analysis appears anachronistic. In the so-called global era, at the wane and collapse of the jus publicum Europaeum, one can no longer "hide" the individual within the frame of the state and entrust the formation and mediation of values to the fictio of sovereignty. The unlimited potential of man can no longer be chained to a political form (as Schmitt argues in his Political Theology). The real problem of sovereign power, then, does not lie in having "denuded" human's life - i.e. as in Hobbes, in having transformed security in control and freedom in biopolitics - but in having considered human potential and freedom an universal threat. This means that Schmitt's idea of modernity can be read as the desperate attempt to control the uncontrollable; i.e. the infinite human capacity understood as a contingency, so ending up stripping away life of its form-of-life, transforming it in mere naked life. But today we are aware that the friend-enemy dialectic no longer generates neither form nor unity but only violent confrontation. In the post-Auschwitz world it is no longer acceptable to attribute to the "power of the elements" the political destiny of human beings. As Taubes (1993/2004, p. 109) poetically wrote contra Schmitt: 'Earth and sea - without human beings, the elements after all remain 'matter' (not even 'matter') - When humanism has been depleted [...] then that only means, does it not, that the question concerning human being is just posed more radically."

Today, paradoxically, we find ourselves in front of the situation that Schmitt had described already in 1914:

There are times of mediation and times of immediacy. In the latter, the devotion of the individual to the Idea is something people take for granted. There is no need for a highly organized state to support the recognition of law [Recht]; on the opposite, the state seems to stand, according to Angelus Silesius' saying, like a wall before the light. (Schmitt, 1914, p. 108)

In the immediacy of the global world, we can no longer nullify ourselves in the totality of the state, in the hope of being protected from our anxieties by giving up our ethical choices. Today, in a novel and immediate form, history calls us forcefully to choose 
our fate. In the mare magnum produced by contemporary globalization, the individual - if she does not want to sink in the chaotic flow of events - is called to a moral decision, to look into this formless tide to find guidance, meaning, and, above all, the sense of her otherness. In substance, Max Weber's problem is still with us. Yet the question of values, of their implementation and reversibility, presents itself to us in a more radical and post-statual form, and requires a choice and an even greater responsibility. Just as Däubler (1916/1919, p. 65) had sung in an enigmatic poetry, central to understanding the work of Schmitt:

The enemy is the embodiment of our own question.

And he becomes us; we chase him to the same end.

But violence comes from people's prudence.

The ancestors meet themselves on the promontories

And remain silent when the tide clashes with the tide. ${ }^{26}$

\section{Acknowledgements}

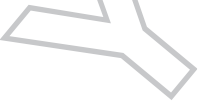

I wish to thank Arthur Bradley, Bülent Diken, Michael Dillon, Charlie Gere, and Gavin Hyman for their invaluable intellectual support and friendship; Jonathan Colman and Martin O'Brien for being always willing to discuss new research ideas; and Timo Pelz for helping me with the German translation.

\section{Disclosure statement}

No potential conflict of interest was reported by the author.

\section{Notes}

25 1. "Das Böse ist der Sternhimmel des Guten."

2. Cf. Weber $(1949$, pp. 55, 112) and Schmitt $(1929 / 2007$, pp. 82-89).

3. This is the guiding idea of the seminal works by Ulmen $(1985,1991)$. For a similar interpretation, which analyses the Weber-Schmitt relationship within the larger frame of the crisis of modernity, see Galli (1996, pp. 77-122).

30 4. For an overview, see Engelbrekt (2009).

5. I follow the analytical distinction developed by Colliot Thélène but I don't agree with her conclusions. First, it is an oversimplification to define Weber an "economist" (even though Weber sometimes defines himself - for intellectual humility - in this way). Second, it is misleading to stigmatize Weber's theory of rationalization as a teleological and irreversible process (on this point see, Weiss, 1987). Finally, as I shall explain, if Schmitt, unlike Weber, fights against the "disenchantment" is just because he "ideologizes" politics and law in a way that would be too one-sided to Weber.

6. The original text is a lecture delivered by Schmitt in a seminar organized by his friend Ernst Forsthoff in the town of Ebrach on 23 October 1959. Along with Schmitt, other important scholars attended the meeting including Joachim Ritter, Julien Freund, Reinhard Koselleck, Arnold Gehlen, Ernst-Wolfgang Böckenförde. The original theme of the seminar was "The Dissolution of the Unity of Science" (cf. Mußgnug, Mußgnug, \& Reinthal, 2007, p. 149). However, after Forsthoff's speech on "Virtue and Value in the Theory of the State" (Tugend und Wert in der Staatslehre) the debate shifted on this topic. Schmitt's contribution was first printed in a volume "not for sale" dedicated to those who were in Ebrach, cf. Schmitt, C. (1960). Die Tyrannei der Werte. Überlegungen eines Juristen zur Wert-Philosophie, 200 copies. Stuttgart: Kohlhammer. A shorter German version was released, without Schmitt's knowledge, in the Frankfurter Allgemeine Zeitung 146 (27 June 1964). For this reason, the 
"unaltered" [unverändert] document, with a new introduction, was included in a volume issued in honor of Forsthoff's sixty-fifth birthday, cf. Schmitt, C. (1967). Die Tyrannei der Werte. In S. Buve (Hrsg.), Säkularisation und Utopie. Ebracher Studien. Ernst Forsthoff zum 65 Geburstag (pp. 37-62). Stuttgart: Kohlhammer. Schmitt's borrows the expression Tyranny of Values from Nicolai Hartmann's Ethics (1926/1932, p. 423): "Every value when once it has gained power over a person - has the tendency to set itself up as sole tyrant of the whole human ethos, and indeed at the expense of other values, even of such as are not inherently opposed to it." I have translated the German word Werte with "values" and not with "valors" to respect Schmitt's intension. For, in one of his last public appearances (9 November 1982), Schmitt (2005, pp. 177-8) interviewed by Fulco Lanchester for the Italian journal Quaderni Costituzionali pointed out that "the essay [The Tyranny of Values] is focused on the conflict among values. I argue that value is a concept that leads ineffably to economization. What is the highest value? An answer can be found only if you have already rightly economized. You see, this is my thesis. And now the new Pope John Paul II speaks of values and doesn't know what he is talking about referring to German philosophers such as Max Scheler. It is so sad and I feel very sorry for this. What should we do? This is very dangerous.".

7. The expression appears in the Inaugural Lecture delivered by Weber in May 1895 at Freiburg University. Cf. Weber $(1895 / 2007$, p. 27). On the various meanings of this concept, see Roth (1984).

8. On Weber and Lukács, see Gluck (1985) and Weber (1988, pp. 465-466).

9. See also Gerth's reply (1945).

10. It is not my intention to criticize Mommsen. Moreover, in the preface to the English edition (1984, p. vii), he recognizes some of the limitations of his work: "This book was written in a political climate of a rather specific kind, colored by the determination of a whole generation of Germans to make democracy work after all. Those historians who began their academic work in the 1950s were especially influences by the West European and American examples; 'reeducation' had left an intellectual mark on many of them. (...) These historians tended to adopt a fundamentalist conception of democracy, which emphasized its base in the inalienable rights of natural law. (...) The writing of this book was strongly influenced by this trend, and it undoubtedly owes some of its strengths, but possibly also some of its shortcomings, to the singular intellectual constellation that existed in the Federal Republic of Germany in the 1950s.".

11. Cf. Weber (2012), pp. 3-94. On the formal and substantive unity of Weber's work, see Wolin (1981).

12. See also Schmitt (1919/1985, p. 52): "Modern philosophy is governed by a schism between thought and being, concept and reality, mind and nature, subject and object, that was not eliminated even by Kant's transcendental solution.".

13. See also McCormick (1997, pp. 31-82).

14. For an attempt to reconstruct the "fragmented" relationship between Weber and Schmitt, see McCormick (1997, pp. 206-12).

15. In my short genealogical reconstruction of the word "value", I consider only those authors who are crucial in order to contextualize Weber and Schmitt's positions. For further discussion, see the entries "valŏur" and "valūe" in Middle English Dictionary, ed. R.E. Lewis (Ann Arbour, MI: The University of Michigan Press, 1997), pp. 501-3; The Oxford English Dictionary, vol. XIX, ed. J.A. Simpson and E.S.C. Weiner (Oxford: Clarendon Press, 1989), pp. 414-18; Dictionnaire de l'ancienne langue française, vol. X, ed. F. Godefroy (New York: Krauss, 1961), pp. 828-9; and "Wert" in Historisches Wörterbuch der Philosophie, vol. XII, ed. J. Ritter and R. Eisler (Basel: Schwabe, 2004), pp. 556-91. See also Volpi (2008), which I partially follow here.

16. On Weber's reservations concerning the term "value", see his letters to Marianne Weber and Heinrich Rickert, and the "Nervi's Fragment" in Weber (2012, pp. 374-5, 413-4).

17. Schmitt's borrows this idea from Heidegger (1943/2002, p. 170). As a matter of fact, the influence of Heidegger on Schmitt's "critique of values" is crucial.

18. It is worth pointing out that in Hobbes' system there are no clear traces of the transition from the Good - understood as an objective fulcrum upon which to establish the Commonwealth - to values - understood as expression of free subjectivities. In this regards, he writes: "I observe the Diseases of a Common-wealth, that proceed from the poyson of 
seditious doctrines; whereof one is, That every private man is Judge of Good and Evill actions" (Hobbes, 1651/2005, p. 255).

19. Cf. the Latin edition, Hobbes (1668/1961), p. 137.

20. For a critical account of the Weber-Rickert relation, see Oakes (1988).

21. It is worth citing a passage of the so-called "Nervi fragment" in which Weber's (1903/ 2012, pp. 413-414) intellectual distance from Rickert is evident: "As soon as one tries to look for something different, something objective, behind the fact that, in any given instance, historical interest will be limited and graduated, one enters in the domain of norms; that is to say: one is then looking for a principle from which it would be possible to deduce not only what should, once and for all, be the object of our interest, but [also] to what degree we sh[ould] graduate our interest in the various el[ements] of reality. Precisely that is in fact the meaning - translated into everyday terms - of the 'value metaphysics' with which R[ickert] concludes. Here it must suffice to express doubts as to the possibility of grasping the substance of such norms, and simply to add that such doubts might be consistent with the view that the 'absolute validity' of certain 'values' (what we would call 'interests') could be taken to be more than simply a limiting concept. The logical possibility of a 'formal ethics' at least shows us that the concept of norms [covering] the infinite multiplicity of the object of these norms does not in itself guarantee that [such norms] can be formulated in substance." On this point, see also Bruun (2001).

22. For a similar view, see Hampel (1965), pp. 81-96.

23. It is not a coincidence that Strauss (1953, p. 53-54) uses ideal-typical examples of the Western ethical tradition (prostitution, bravery, nobility of spirit, etc.) to develop his own "objective criticism" of Weber's position. Obviously, these interpretations are value-related and not universal, to say the least. In this regard, it is worth quoting a passage of Heidegger $(1955 / 2003$, p. 122-123) to clarify the question of the ratio and its alleged objective foundation: "The [ratio] is by no means a just judge. It unscrupulously pushes everything not in conformity with it into the presumable swamp of the irrational, which it itself has staked out. Reason and its conceptions are only one kind of thinking and are by no means determined by themselves but by that which has been called thinking, to think in the manner of the ratio. That its dominance arises as rationalization of all categories, as establishing norms, as leveling in the course of the unfolding of European nihilism, provides food for thought, just as do the concomitant attempts at flight into irrational.".

24. For similar remarks, see Weber (2012, pp. 314-15).

35 25. Cf. Weber (1922, p. 246): “[...] nur das formale Element gemeinsam, daß ihr Sinn darauf geht, uns eben die möglichen »Standpunkte« und »Angriffspunkte« der »Wertung« aufzudecken." In the English editions "Angriffspunkte" is translated either as "evaluative approaches" (Weber, 1949, p. 144) or "points of application" (Weber, 2012, p. 157).

26. "Der Feind ist unsre eigne Frage als Gestalt./Und er wird uns, wir ihn zum selben Ende hetzen./Doch aus der Volksbesonnenheit kommt Gewalt./Auf Vorgebirgen treffen sich verwandte Ahnen/Und bleiben stumm, wenn Flut an Flut zerprallt.”.

\section{Notes on contributor}

Antonio Cerella is Lecturer in International Relations at the University of Central Lancashire and Convenor of the BISA Working Group "Contemporary Research on International Political Theory" (CRIPT).

\section{References}

Aquinatis, T. (1862). Summa contra gentiles. Torino: Marietti.

Aristotle. (1894). In F. Susemihl \& R. D. Hicks (Eds.), The politics of Aristotle. London: Macmillan.

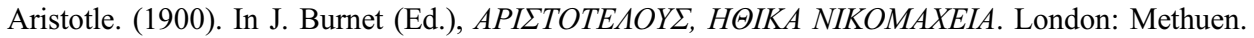

Bendix, R., \& Roth, G. (1971). Scholarship and partisanship: Essays on Max Weber. Berkeley, CA: University of California Press.

Berlin, I. (2001). The originality of Machiavelli. In H. Hardy (Ed.), Against the current. Essays in the history of ideas (pp. 25-79). New York, NY: The Free Press. 
Bruun, H. H. (2001). Weber on Rickert: From value relation to ideal type. Max Weber Studies, 1, $138-160$

Colliot Thélène, C. (1999). Carl Schmitt versus Max Weber: Juridical rationality and economic rationality. In C. Mouffe (Ed.), The challenge of Carl Schmitt (pp. 138-154). London: Verso.

Däubler, T. (1916/1919). Hymne an Italien. Leipzig: Insel-Verlag.

Engelbrekt, K. (2009). What Carl Schmitt picked up in Weber's seminar: A historical controversy revisited. The European Legacy, 14, 667-684.

Factor, A. R., \& Turner, S. P. (1979). The limits of reason and some limitations of Weber's morality. Human Studies, 2, 301-334.

Galli, C. (1996). Genealogia della politica. Carl Schmitt e la crisi del pensiero politico moderno. Bologna: Il Mulino.

Gerth, H. H. (1945). Max Weber's politics: A rejoinder. Politics, 3, 119-120.

Gluck, M. (1985). Georg Lukács and his generation: 1900-1918. Cambridge, MA: Harvard University Press.

Habermas, J. (1971). Discussion on 'value freedom and objectivity'. In O. Stammer (Ed.), Max Weber and sociology today (pp. 59-66). Oxford: Basil Blackwell.

Hampel, C. G. (1965). Aspect of scientific explanation and other essay-in the philosophy of science. New York, NY: The Free Press.

Hartmann, N. (1926/1932). Ethics. Volume II. Moral values. London. Allen and Unwin.

Heidegger, M. (1943/2002). Nietzsche's word: 'God is dead'. In J. Young \& K. Haynes (Eds.), Off the beaten track (pp. 157-199). Cambridge: Cambridge University Press.

Heidegger, M. (1955/2003). The question of being. In M. Strassen (Ed.), Philosophical and political writings (pp. 120-151). New York, NY: Continuum.

Hobbes, T. (1651/2005). Leviathan. London: Continuum.

Hobbes, T. (1668/1961). Leviathan. Sive de materia, forma, et postestate civitatis ecclesiastica et civilis. Aalen: Scientia.

Jeffers, R. (1941/2011). The bloody sire. In T. Hunt (Ed.), The selected poetry of Robinson Jeffers (p. 563). Stanford, CA: Stanford University Press.

Kafka, F. (1992). Oktavheft G (II, 2), December 6, 1917. In J. Schillemeit (Ed.), Nachgelassene Schriften und Fragmente II (p. 57). Frankfurt a.M: S. Fisher.

Kant, I. (1797/1996). The metaphysics of morals. Cambridge: Cambridge University Press.

Löwith, K. (1932/1993). Max Weber and Karl Marx. London: Routledge.

Löwith, K. (1935/1998). The occasional decisionism of Carl Schmitt. In R. Wolin (Ed.), Heidegger and European nihilism (pp. 137-169). New York, NY: Columbia University Press.

Löwith, K. (1964). Die Entzauberung der Welt durch Wissenschaft. Zu Max Webers 100. Geburtstag. Merkur, 18, 501-519.

Lukács, G. (1980). The destruction of reason. (P. Palmer, Trans.). London: Merlin Press.

McCormick, J. P. (1997). Carl Schmitt's critique of liberalism. Cambridge: Cambridge University Press.

McCormick, J. P. (1998). Transcending Weber's categories of modernity? The early Lukacs and Schmitt on the rationalization thesis. New German Critique, 75, 133-177.

Mommsen, W. J. (1984). Max Weber and German politics, 1890-1920. (M. S. Steinberg, Trans.). Chicago, IL: The University of Chicago Press.

Mußgnug, D., Mußgnug, R., \& Reinthal, A. (2007) (Hrsg.). Ernst Forsthoff - Carl Schmitt. Briefwechsel 1926-1974. Berlin: Akademie Verlag.

Nietzsche, F. (1874/2007). On the uses and disadvantages of history for life. In D. Breazeale (Ed.), Untimely meditations (pp. 59-123). Cambridge: Cambridge University Press.

Nietzsche, F. (1886/2002). Beyond good and evil. (J. Norman, Trans.). Cambridge: Cambridge University Press.

Nietzsche, F. (1906/1968). The will to power. (W. Kaufmann, Trans.). New York, NY: Vintage.

Oakes, G. (1988). Weber and Rickert. Concept formation in the cultural sciences. Cambridge, MA: MIT Press.

Ortega y Gasset, J. (1923/2004). Introducción a una Estimativa. ¿Que son los valores? Madrid: Ediciones Encuentro.

Plato. (1902). In J. Adam, (Ed.), The republic of Plato. Cambridge: Cambridge University Press.

Plotinus. (1956) The enneads. (S. MacKenna, Trans.). London: Faber and Faber.

Rickert, H. (1902/1986). The limits of concept formation in natural science. (G. Oakes, Trans.). Cambridge: Cambridge University Press. 
Roth, G. (1984). Max Weber's ethics and the peace movement today. Theory and Society, 13, 491-511.

5 Schapiro, M. (1945). A note on Max Weber's politics. Politics, 2, 44-48.

Scheler, M. (1916/1973). Formalism in ethics and non-formal ethics of values. A new attempt toward the foundation of an ethical personalism. (M. S. Frings, \& R. L. Funk, Trans.). Evanston, IL: Nothwestern University Press.

Schmitt, C. (1914). Der Wert des Staates und die Bedeutung des Einzelnen. Tübingen: Mohr. 10 Schmitt, C. (1919/1985). Political romanticism. (G. Oakes, Trans.). Cambridge, MA: MIT Press.

Schmitt, C. (1929/2007). The age of neutralizations and depoliticizations. In G. Schwab (Ed.), The concept of the political (pp. 80-95). Chicago, IL: The University Chicago Press.

Schmitt, C. (1930/1999). Ethic of state and pluralistic state. In C. Mouffe (Ed.), The challenge of Carl Schmitt (pp. 195-208). London: Verso.

Schmitt, C. (1932/2007) The concept of the political. Chicago, IL: The University of Chicago Press.

Schmitt, C. (1950/2001). The question of legality. In S. Draghici (Ed.), State, movement, people. The triadic structure of the political unity (pp. 55-64). Corvellis, OR: Plutarch Press.

$\mathrm{AQ} 370$

AQ38

ÂQ39

Schmitt, C. (1960/2011). Die Tyrannei der Werte. Dritte, korrigierte Auflage. Berlin: Duncker \& Humblot.

Schmitt, C. (1991). Glossarium. Aufzeichnungen der Jahre 1947-1951. Berlin: Duncker \& Humblot.

Schmitt, C. (2005). Un giurista davanti a se stesso. Saggi e interviste. Vicenza: Neri Pozza.

Simon, H. A. (1983). Reason in human affairs. Stanford, CA: Stanford University Press.

Strauss, L. (1953). Natural right and history. Chicago, IL: The University of Chicago Press.

Taubes, J. (1993/2004). The political theology of Paul. Stanford, CA: Stanford University Press.

Topitsch, E. (1971). Max Weber and sociology today. In O. Stammer (Ed.), Max Weber and sociology today (pp. 8-25). Oxford: Basil Blackwell.

Ulmen, G. L. (1985). The sociology of the state: Carl Schmitt and Max Weber. State, Culture, and Society, 1, 3-57.

Ulmen, G. L. (1991). Politischer Mehrwert: Eine Studie über Max Weber und Carl Schmitt. Weinheim: VCH Acta humaniora.

Volpi, F. (2008). Anatomia dei valori. In C. Schmitt (Ed.), La tirannia dei valori (pp. 71-107). Milano: Adelphi.

Weber, M. (1895/2007). The nation state and economic policy. In P. Lassman \& R. Speirs (Eds.), Weber: Political writings (pp. 1-28). Cambridge: Cambridge University Press.

Weber, M. (1918/2007). Parliament and government in Germany under a new political order. In P. Lassman \& R. Speirs (Eds.), Weber: Political writings (pp. 130-271). Cambridge: Cambridge University Press.

Weber, M. (1922). Gesammelte Aufsätze zur Wissenschaftslehre. Tübingen: Mohr.

Weber, M. (1946). From Max Weber: Essays in sociology. (H. H. Gerth, \& C. Wright Mills, Trans.). New York, NY: Oxford University Press.

Weber, M. (1949). In E. A. Shils \& H. A. Finch (Eds.), The methodology of the social sciences. Glencoe, IL: The Free Press.

Weber, M. (1988). Max Weber. A biography. New Brunswick, NJ: Transaction.

Weber, M. (2012). Collected methodological writings. (H. H. Bruun, Trans.). New York, NY: Routledge.

Weiss, J. (1987). On the irreversibility of western rationalization and Max Weber's alleged fatalism. In S. Lash \& S. Whimster (Eds.), Max Weber, rationality and modernity (pp. 154-163). London: Allen \& Unwin.

Windelband, W. (1914/1921). An introduction to philosophy. (J. McCabe, Trans.). London: T. Fisher Unwin.

Wolin, S. (1981). Max Weber: Legitimation, method, and the politics of theory. Political Theory, $9,401-424$. 